\title{
Effect of environmental factors on the abundance of decapod crustaceans from soft bottoms off southeastern Brazil
}

\author{
MICHELE FURLAN ${ }^{1}$, ANTONIO L. CASTILHO ${ }^{1}$, LISSANDRA C. FERNANDES-GÓES $^{2}$, \\ VIVIAN FRANSOZO ${ }^{3}$, GIOVANA BERTINI ${ }^{4}$ and ROGÉRIO C. DA COSTA ${ }^{5}$ \\ ${ }^{1}$ Departamento de Zoologia, Instituto de Biociências, Universidade Estadual Paulista/UNESP, \\ Distrito de Rubião Junior, s/n, 18618-000 Botucatu, SP, Brasil \\ ${ }^{2}$ Universidade Estadual do Piauí/UESPI, Av. Nossa Senhora de Fátima, s/n, 64202-220 Parnaíba, PI, Brasil \\ ${ }^{3}$ Departamento de Ciências Naturais, Universidade Estadual do Sudoeste da Bahia/UESB, \\ Estrada do Bem Querer, Km 04, 45031-900 Vitória da Conquista, BA, Brasil \\ ${ }^{4}$ Universidade Estadual Paulista/UNESP, Unidade de Registro, Rua Nelson Brihi Badur, 430, 11900-000 Registro, SP, Brasil \\ ${ }^{5}$ Departamento de Ciências Biológicas, Faculdade de Ciências, Universidade Estadual Paulista/UNESP, \\ Av. Luiz Edmundo Carrijo Coube, 14-01, 17033-360 Bauru, SP, Brasil
}

Manuscript received on February 2, 2012; accepted for publication on September 13, 2012

\begin{abstract}
This study investigated the importance of variations in environmental factors affecting the abundance patterns of decapods on the southeastern Brazilian coast. Sampling was carried out monthly from January 1998 through December 1999 in Ubatumirim and Mar Virado, Ubatuba region, using a commercial shrimp fishing boat equipped with double-rig nets. Six areas adjacent to rocky shores were chosen. Bottom-water samples were collected using a Nansen bottle, to measure the temperature and salinity. Sediment samples were also obtained by means of a Van Veen grab, for determination of texture and organic-matter content. The association of environmental factors with species abundance was evaluated by Canonical Correspondence Analysis $(\alpha=0.05)$. Forty-one species of Decapoda were used in the multivariate analysis. The analysis indicated that sediment texture (phi) and bottom temperature were the main factors correlated $(p<0.05)$ with the spatial and temporal abundance of the species. Considering the study region as faunal transition zone, including a mixture of species of both tropical and subantarctic origin, the species responded differently to environmental factors, mainly temperature. It is conceivable that the decapods adjust their distribution according to their intrinsic physiological limitations, possibly as a result of the available resources.
\end{abstract}

Key words: benthic species, decapod crustaceans, environmental factors, habitat selection.

\section{INTRODUCTION}

Benthic communities have received much attention in recent years, mainly concerning ecological descriptions of coastal areas, as such investigations are fundamental in assessing possible environmental impacts (Bertini et al. 2010). Among the

Corresponding author: Michele Furlan

E-mail:mfurlan@ibb.unesp.br environmental problems in the Ubatuba region, trawling seriously affects the structure of the entire marine communities (Garcia and Le Reste 1981, Pauly et al. 2002). This damage is related to the excessive catch of accessory species (bycatch) along with those of economic interest (Alverson et al. 1994). Shrimp fisheries along the southeastern Brazilian coast have targeted the most profitable species, 
such as the shrimps Farfantepenaeus brasiliensis (Latreille, 1817) and F. paulensis (Pérez-Farfante, 1967), Litopenaeus schmitti (Burkenroad, 1936), Xiphopenaeus kroyeri (Heller, 1862), Artemesia longinaris Bate, 1888 and Pleoticus muelleri (Bate, 1888) (Costa et al. 2004, Castro et al. 2005, Castilho et al. 2007). In addition to shrimp, swimming crabs (Portunidae) are also commercially exploited (Negreiros-Fransozo et al. 1999).

According to Boschi (2000), the southwestern Atlantic Ocean can be divided into two provinces based on the distribution of decapod crustaceans: the Argentinian Province (from $43-44^{\circ} \mathrm{S}$ to $23^{\circ} \mathrm{S}$ ), which includes the coastal waters of Patagonia, Argentina, Uruguay and Brazil (to Cabo Frio, Rio de Janeiro); and the Brazilian Province (from $23^{\circ} \mathrm{S}$ to $8^{\circ} \mathrm{N}$ ), which occupies a large extent of the tropical and subtropical coast of northern and northwestern Brazil, French Guiana, Suriname, Guyana and a small part of Venezuela (to the mouth of the Orinoco River). Located on the northern coast of São Paulo State, Brazil, the Ubatuba region $\left(23^{\circ} \mathrm{S}\right)$ is an important area for crustacean investigations. This region is a transition area between the two provinces characterized by processes of mixing and instability of the water masses (Boschi 2000), with a mixture of faunas of both tropical/subtropical and temperate origin.

The distribution limits of the majority of marine benthic organisms are determined by a complex set of environmental factors acting throughout their life cycles (Bertini et al. 2010). The presence and success of an organism or group of organisms depend on many factors. For marine benthic species, their distribution and abundance are limited by the temperature, salinity, depth, texture of the sediment, and organic matter, as well as intra- and inter-specific relationships. These environmental factors may act in isolation or together (Meireles et al. 2006).

In the region off Ubatuba (southeastern Brazilian coast), only Pires (1992) and Sumida and Pires-Vanin (1997) have studied the distribution of benthic organisms as a whole, in relation to environmental factors. The association of some individual decapods with environmental factors was examined by Fransozo et al. (1992, 1998, 2002, 2008, 2011), Negreiros-Fransozo et al. (1997), Mantelatto and Fransozo (2000), Bertini and Fransozo (2004), Castilho et al. (2008) and Bertini et al. (2010). The objective of the present study was to comprehend how variations in environmental factors (bottom temperature and salinity, sediment texture and organic-matter content) affect the abundance of decapod crustaceans inhabiting the Ubatuba region, by means of a multivariate analysis.

\section{MATERIALS AND METHODS}

SAMPLING OF SPECIMENS AND ENVIRONMENTAL FACTORS

Sampling was carried out monthly from January 1998 through December 1999 in Ubatumirim and Mar Virado, located in the Ubatuba region on the northern coast of São Paulo State. Six areas adjacent to rocky shores were defined, four within bays and two near islands (Fig. 1). The samples were taken at depths of $5 \mathrm{~m}$ to $17 \mathrm{~m}$. A GPS (Global Positioning System) was used to record the position of each sampling site.

The shrimp boat used for trawling was equipped with double-rig nets (mesh size $20 \mathrm{~mm}$ and $15 \mathrm{~mm}$ in the cod end). Each sampling area $(2 \mathrm{Km})$ was trawled over a $30-$ min period, covering $18,000 \mathrm{~m}^{2}$, in the morning.

In the laboratory, the specimens were identified according to specific references for each group: Pérez-Farfante and Kensley (1997) and Costa et al. (2003) for Penaeidea; Holthuis (1993), L.F.R. Guterres (unpublished data), Rhyne and Lin (2006) and Ferreira et al. (2010) for Caridea; Melo (1996) for Brachyura; and Melo (1999) for Anomura. The taxonomic classification was based on De Grave et al. (2009).

Bottom-water samples were collected monthly in each sampling area, with a Nansen bottle, to measure temperature and salinity. Temperature was measured with a mercury thermometer $\left({ }^{\circ} \mathrm{C}\right)$ with accuracy of $1{ }^{\circ} \mathrm{C}$, and salinity using an optical 

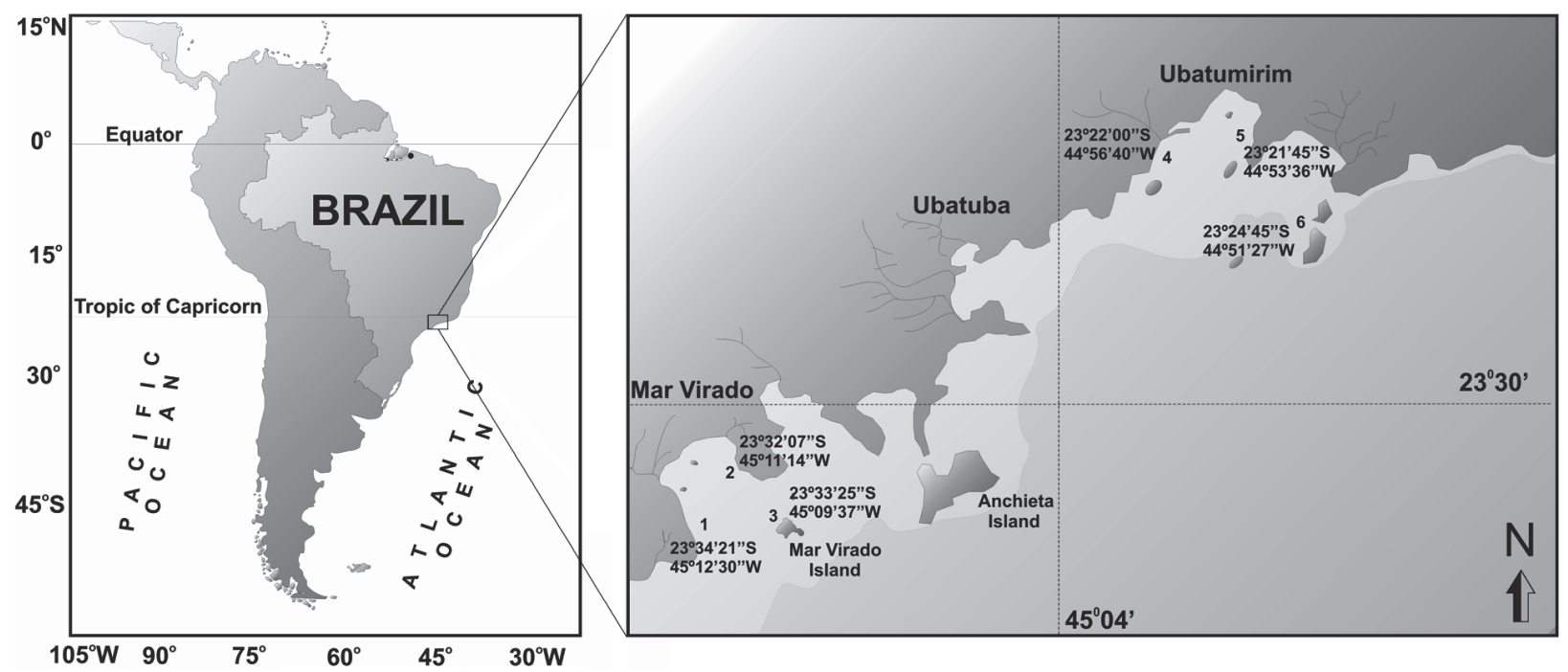

Fig. 1 - Ubatuba region, indicating the sampling areas.

refractometer (Atago S/1000, Tokyo), with the result expressed in parts per thousand. Only the data for bottom temperature and salinity were used in the analysis, due to the benthic habits of the decapods.

Sediment samples were obtained in each season with a $0.06 \mathrm{~m}^{2}$ Van Veen grab, for analysis of texture and organic-matter content. In the laboratory, the sediment was oven-dried at $70^{\circ} \mathrm{C}$ for $72 \mathrm{~h}$. For the analysis of grain-size composition, two sub-samples of $50 \mathrm{~g}$ were treated with 250 $\mathrm{mL}$ of $\mathrm{NaOH}$ solution $(0.2 \mathrm{~mol} / \mathrm{L})$ and stirred for 5 min to release silt and clay particles. Then, the sub-samples were rinsed on a $0.063 \mathrm{~mm}$ sieve. The remaining sediment was again oven-dried at $60^{\circ} \mathrm{C}$ for $24 \mathrm{~h}$ and screened through six sieves of different mesh sizes. Grain-size categories followed the Wentworth (1922) American standard. The phi values were calculated, obtaining classes from -1 to greater than 4 . The highest phi values correspond to the finest sediment, and the lowest values to the coarsest sediment. From the values obtained, the measures of central tendency were calculated, to determine the most frequent granulometric fractions in the sediment (Suguio 1973, Tucker 1988). The organic-matter content of the sediment in each area was estimated as the difference between the initial and ash-free dry weights of three subsamples (10 $\mathrm{g}$ each) incinerated in porcelain crucibles at $500^{\circ} \mathrm{C}$ for $3 \mathrm{~h}$.

\section{DATA ANALYSIS}

The relationship between the environmental factors measured and the benthic communities was analyzed by means of multivariate analysis. This statistical technique indicates broad trends in faunal composition and their association with environmental factors (Colloca et al. 2003, De Léo and Pires-Vanin 2006, Lui et al. 2007, EscobarBriones et al. 2008, Bertini et al. 2010).

Considering the 144 trawls performed, those species with a frequency of occurrence lower than $5 \%$, i.e., those which did not appear in at least 8 samples, were not used in the multivariate analysis, due to their low power of influence in the analysis. Thus, 41 species from the total of 80 species caught were included in the Canonical Correspondence Analysis (CCA) and cluster method.

The CCA $(\alpha=5 \%)$, ran with the software CANOCO for Windows 4.5, was used in order to evaluate the association of the environmental variables (bottom temperature and salinity, sediment texture and organic matter) with the species abundance. Abundance data were log-transformed for the analysis, to improve their normality (Zar 1999). 
Cluster analysis was performed using species abundance. The species were grouped according to the Bray-Curtis similarity index, followed by the unweighted-pair group averaging (UPGMA) cluster method (Zar 1999).

All samples from both localities were incorporated into the same analysis. This approach is justified given that the goal was not to characterize each sampling location. Instead, by including the widest possible variation in environmental parameters, one would expect that the effects of these parameters on the decapod crustaceans would become more apparent.

\section{RESULTS}

A total of 157,072 individuals were collected, distributed in 41 species (Table I). The shrimp $X$. kroyeri was the most abundant (83.8\%), followed by swimming crab Callinectes ornatus Ordway, 1863 (4.9\%) and caridean shrimp Exhippolysmata oplophoroides (Holthuis, 1948) (2.5\%). Together, these three species comprised $91.2 \%$ of all individuals collected.

Among the 41 species in the multivariate analysis, 9 belong to Penaeidea, 4 to Caridea, 9 to Anomura and 19 to Brachyura.

TABLE I

Data for environmental variables and the numbers of individuals of species with a frequency of occurrence greater than 5\%, during the study period (January 1998 through December 1999) in the Ubatuba region.

\begin{tabular}{|c|c|c|c|c|c|}
\hline Environmental variables & Mean & SD & Range & & \\
\hline Bottom temperature $\left({ }^{\circ} \mathrm{C}\right)$ & 24.3 & 2.38 & $16.5-29.7$ & & \\
\hline Bottom salinity & 34.4 & 1.56 & $28.0-37.0$ & & \\
\hline Organic-matter content & 4.21 & 4.21 & $0.6-12.8$ & & \\
\hline Phi & 4.5 & 0.86 & $3.32-5.84$ & & \\
\hline Depth (m) & 9.2 & 4.11 & $4.7-16.8$ & & \\
\hline Species & & & & $\mathbf{N}$ & Abb \\
\hline Xiphopenaeus kroyeri (Heller, 1862) (PE) & 914.24 & $1,476.79$ & $0-7,072$ & 131,651 & $X k r$ \\
\hline Callinectes ornatus Ordway, 1863 (BR) & 53.35 & 86.67 & $0-614$ & 7,682 & Cor \\
\hline Exhippolysmata oplophoroides (Holthuis, 1948) (CA) & 27.23 & 69.68 & $0-410$ & 3,921 & Eop \\
\hline Litopenaeus schmitti (Burkenroad, 1936) (PE) & 14.99 & 43.01 & $0-382$ & 2,159 & $L s c$ \\
\hline Hepatus pudibundus (Herbst, 1785) (BR) & 9.44 & 12.55 & $0-60$ & 1,359 & Hpu \\
\hline Rimapenaeus constrictus (Stimpson, 1874) (PE) & 9.42 & 16.42 & $0-87$ & 1,357 & Rco \\
\hline Dardanus insignis (de Saussure, 1858) (AN) & 8.49 & 20.42 & $0-178$ & 1,222 & $\operatorname{Din}$ \\
\hline Callinectes danae Smith, 1869 (BR) & 8.42 & 16.88 & $0-109$ & 1,212 & $C d a$ \\
\hline Farfantepenaeus brasiliensis (Latreille, 1817) (PE) & 7.55 & 20.38 & $0-187$ & 1,087 & $\mathrm{Fbr}$ \\
\hline Hexapanopeus paulensis Rathbun, 1930 (BR) & 6.28 & 16.27 & $0-127$ & 905 & Hpa \\
\hline Sicyonia dorsalis Kingsley, 1878 (PE) & 4.90 & 16.50 & $0-125$ & 706 & Sdo \\
\hline Farfantepenaeus paulensis (Pérez Farfante, 1967) (PE) & 3.33 & 10.69 & $0-112$ & 480 & Fpa \\
\hline Porcellana sayana (Leach, 1820) (AN) & 3.03 & 6.80 & $0-35$ & 437 & Psa \\
\hline Pleoticus muelleri (Bate, 1888) (PE) & 2.18 & 9.10 & $0-83$ & 314 & Pmu \\
\hline Hexapanopeus schmitti Rathbun, 1930 (BR) & 2.01 & 5.95 & $0-45$ & 290 & $H s c$ \\
\hline Nematopalaemon schmitti (Holthuis, 1950) (CA) & 1.75 & 6.20 & $0-42$ & 252 & $N s c$ \\
\hline Arenaeus cribrarius (Lamarck, 1818) (BR) & 1.60 & 2.26 & $0-11$ & 230 & Acr \\
\hline Loxopagurus loxocheles (Moreira, 1901) (AN) & 1.53 & 5.28 & $0-48$ & 221 & Llo \\
\hline Portunus spinimanus Latreille, 1819 (BR) & 1.35 & 2.67 & $0-14$ & 194 & Pspm \\
\hline
\end{tabular}

SD: standard deviation, N: abundance, Abb: abbreviation. PE: Penaeidea, CA: Caridea, AN: Anomura, BR: Brachyura. 
TABLE I (continuation)

\begin{tabular}{|c|c|c|c|c|c|}
\hline Species & & & & $\mathbf{N}$ & Abb \\
\hline Artemesia longinaris Bate, $1888(\mathrm{PE})$ & 1.16 & 4.04 & $0-33$ & 167 & Alo \\
\hline Petrochirus diogenes (Linnaeus, 1758) (AN) & 1.13 & 3.22 & $0-32$ & 163 & $P d i$ \\
\hline Alpheus intrinsecus Bate, 1888 (CA) & 1.05 & 2.92 & $0-17$ & 151 & Ain \\
\hline Portunus spinicarpus (Stimpson, 1871) (BR) & 1.00 & 8.45 & $0-100$ & 144 & Pspc \\
\hline Libinia spinosa $\mathrm{H}$. Milne Edwards, 1834 (BR) & 0.72 & 3.11 & $0-32$ & 104 & $L s p$ \\
\hline Paguristes erythrops Holthuis, 1959 (AN) & 0.78 & 3.26 & $0-33$ & 91 & Per \\
\hline Persephona punctata (Linnaeus, 1758) (BR) & 0.63 & 1.28 & $0-7$ & 91 & Ppu \\
\hline Libinia ferreirae Brito Capello, 1871 (BR) & 0.53 & 1.59 & $0-15$ & 76 & $L f e$ \\
\hline Charybdis hellerii (A. Milne Edwards, 1867) (BR) & 0.43 & 1.32 & $0-10$ & 62 & Che \\
\hline Persephona mediterranea (Herbst, 1794) (BR) & 0.33 & 1.04 & $0-10$ & 48 & Pme \\
\hline Moreiradromia antillensis (Stimpson, 1858) (BR) & 0.31 & 0.79 & $0-5$ & 45 & Mant \\
\hline Minyocerus angustus (Dana, 1852) (AN) & 0.27 & 1.02 & $0-8$ & 39 & Man \\
\hline Leander paulensis Ortmann, 1897 (CA) & 0.26 & 1.71 & $0-19$ & 38 & Lpa \\
\hline Sicyonia typica (Boeck, 1864) (PE) & 0.35 & 0.79 & $0-18$ & 33 & Sty \\
\hline Pagurus brevidactylus (Stimpson, 1859) (AN) & 0.20 & 0.87 & $0-9$ & 29 & $\mathrm{Pbr}$ \\
\hline Pagurus exilis (Benedict, 1892) (AN) & 0.17 & 0.63 & $0-5$ & 24 & Pex \\
\hline Stenorhynchus seticornis (Herbst, 1788) (BR) & 0.16 & 0.78 & $0-8$ & 23 & Sse \\
\hline Pyromaia tuberculata (Lockington, 1876) (BR) & 0.13 & 0.67 & $0-7$ & 18 & Ptu \\
\hline Pilumnus dasypodus Kingsley, 1879 (BR) & 0.10 & 0.48 & $0-4$ & 14 & $P d a$ \\
\hline Notolopas brasiliensis Miers, 1886 (BR) & 0.08 & 0.42 & $0-4$ & 12 & $\mathrm{Nbr}$ \\
\hline Persephona lichtensteinii Leach, 1817 (BR) & 0.08 & 0.32 & $0-2$ & 12 & $P l i$ \\
\hline Pagurus criniticornis (Dana, 1852) (AN) & 0.06 & 0.27 & $0-2$ & 9 & $\mathrm{Pcr}$ \\
\hline
\end{tabular}

SD: standard deviation, N: abundance, Abb: abbreviation. PE: Penaeidea, CA: Caridea, AN: Anomura, BR: Brachyura.

The CCA revealed that all environmental factors analyzed showed a significant relationship $(\mathrm{p}<0.05)$ to species abundance (Table II); sediment texture (phi) and temperature were both strongly related. The first canonical variables, when summed, explained $90.6 \%$ of the variance. The phi factor was most strongly correlated with individual abundance along the axis of the first canonical variable; and temperature was strongly correlated on the axis of the second canonical variable (Fig. 2).

The grouping analysis indicated four species groups (A, B, C and D), with approximately $20 \%$ similarity. The most abundant species during the entire study period, $X$. kroyeri, and the caridean shrimp Leander paulensis Ortmann, 1897 showed no similarity to the other species collected (Fig. 3). The CCA result indicated that these species showed a positive relationship with phi, on the axis
TABLE II

Results of canonical correspondence analysis, showing the probability of significance $(p)$ of the environmental factors.

\begin{tabular}{lcc}
\hline Environmental variables & $\mathbf{F}$ & $\mathbf{P}$ \\
\hline Bottom temperature $\left({ }^{\circ} \mathrm{C}\right)$ & 5.68 & $0.002^{*}$ \\
Bottom salinity & 1.66 & $0.024^{*}$ \\
Organic-matter content & 2.03 & $0.008^{*}$ \\
Phi & 18.13 & $0.002^{*}$ \\
\hline
\end{tabular}

$* p<0.05$.

of the first canonical variable; i.e., these species were more abundant in fine sediments (Fig. 2).

Group "A" was composed by species with intermediate abundance (Fig. 3 and Table I), which were associated with coarser sediments (i.e., negatively related to phi) (Fig. 2). In addition to this relationship with the substratum, the swimming crab Portunus spinicarpus (Stimpson, 1871) was correlated 
TABLE III

Scores for species and environmental variables based on the canonical correspondence analysis. (For abbreviations see Table I.)

\begin{tabular}{|c|c|c|c|c|c|}
\hline \multicolumn{6}{|c|}{ Scores for species } \\
\hline & Axis 1 & Axis 2 & & Axis 1 & Axis 2 \\
\hline Din & 0.87 & 0.32 & Cor & -0.10 & -0.09 \\
\hline Llo & 0.00 & 0.16 & Hpa & 0.61 & -0.21 \\
\hline$P d i$ & 1.00 & 0.22 & Нри & -0.17 & 0.04 \\
\hline Per & 0.67 & -0.37 & $H s c$ & 0.56 & -0.32 \\
\hline $\mathrm{Pbr}$ & -0.01 & -0.15 & Lfe & -0.71 & -0.10 \\
\hline $\mathrm{Pcr}$ & 0.83 & -0.48 & $L s p$ & -0.42 & 0.09 \\
\hline Pex & 0.85 & 0.44 & Mant & 0.79 & 0.25 \\
\hline Man & 0.32 & -0.85 & $\mathrm{Nbr}$ & 0.60 & -0.48 \\
\hline$P s a$ & 1.08 & 0.21 & $P d a$ & 0.99 & -0.08 \\
\hline Alo & -0.75 & 0.44 & $P l i$ & 0.66 & 0.38 \\
\hline $\mathrm{Fbr}$ & 0.33 & -0.27 & Pme & 0.36 & 0.26 \\
\hline Fpa & 0.23 & -0.59 & Pрu & -0.03 & -0.06 \\
\hline$L s c$ & -0.31 & 0.16 & $P s p c$ & 1.23 & 1.20 \\
\hline Rco & 0.03 & 0.08 & Pspm & 0.58 & 0.08 \\
\hline$X k r$ & -0.40 & -0.01 & Ptu & 0.50 & 0.81 \\
\hline Рти & -0.56 & 0.83 & Sse & 1.35 & 0.96 \\
\hline Sdo & -0.44 & 0.25 & Ain & 0.36 & -0.20 \\
\hline Sty & 0.79 & 0.13 & Eop & -0.58 & 0.15 \\
\hline Acr & -0.10 & -0.27 & $N s c$ & -0.55 & 0.06 \\
\hline$C d a$ & -0.11 & -0.28 & Lpa & -0.43 & -0.24 \\
\hline Che & 0.46 & -0.76 & & & \\
\hline \multicolumn{6}{|c|}{ Scores for environmental variables } \\
\hline & Axis 1 & Axis 2 \\
\hline \multicolumn{4}{|c|}{ Bottom temperature (BT) } & -0.00 & -0.95 \\
\hline \multicolumn{4}{|c|}{ Bottom salinity (BS) } & 0.30 & 0.00 \\
\hline \multicolumn{4}{|c|}{ Organic matter (OM) } & 0.14 & 0.14 \\
\hline \multicolumn{4}{|l|}{ Phi } & -0.98 & -0.07 \\
\hline
\end{tabular}

with lower temperatures (negative relationship to temperature). Subgroup “A2'1" was composed by the congener shrimps $F$. paulensis and $F$. brasiliensis. Subgroup "A2'2" was constituted by the host hermit crab Dardanus insignis (de Saussure, 1858) and symbiont porcellanid crab Porcellana sayana (Leach, 1820). Both subgroups were composed by two species with closely related life styles (Fig. 3).

Species with intermediate abundance appeared in subgroup "B1" (Fig. 3 and Table I). In this subgroup, the species were associated with coarser sediments. Exception for the shrimp A. longinaris, which was correlated with finer sediments and lower temperatures; as well as the swimming crab Arenaeus cribrarius (Lamarck, 1818) and the hermit crab Loxopagurus loxocheles (Moreira, 1901), which showed no relationship to the sediment, but did show a relationship to lower and higher temperatures, respectively. Subgroup "B2" united species with low abundance and associated with higher temperatures (Figs. 2 and 3).

The majority of species with high abundance were grouped in "C" (Fig. 3 and Table I). These species showed a negative correlation with temperature and a positive correlation with phi; i.e., they were found at sites with lower temperatures and finer sediments. The exceptions to this group were the swimming crabs $C$. ornatus and Callinectes danae Smith, 1869, which were related to higher temperatures (Fig. 2).

Group "D" combined species with low abundance (Table I), also associated with coarser sediments. Subgroups "D1" and "D2'2" were composed by species that were mainly correlated with lower temperatures, and subgroup "D2'1" with higher temperatures (Figs. 2 and 3).

According to the CCA, the anomuran species were positively correlated with the organic-matter content (Fig. 2).

\section{DISCUSSION}

Our results showed that the abundance and distribution of decapod species depend on a complex of factors, mainly sediment texture and bottom-water temperature. These observations are in accordance with those of Williams (1958), Abele (1974), Dall et al. (1990), Pires (1992), Fransozo et al. (2002, 2008), Scelzo et al. (2002) and Bertini and Fransozo (2004).

Sites with finer substrate showed a greater predominance of penaeids and some brachyuran species. The penaeids and aetrid, portunid and leucosid crabs have a burrowing habit, mainly in 


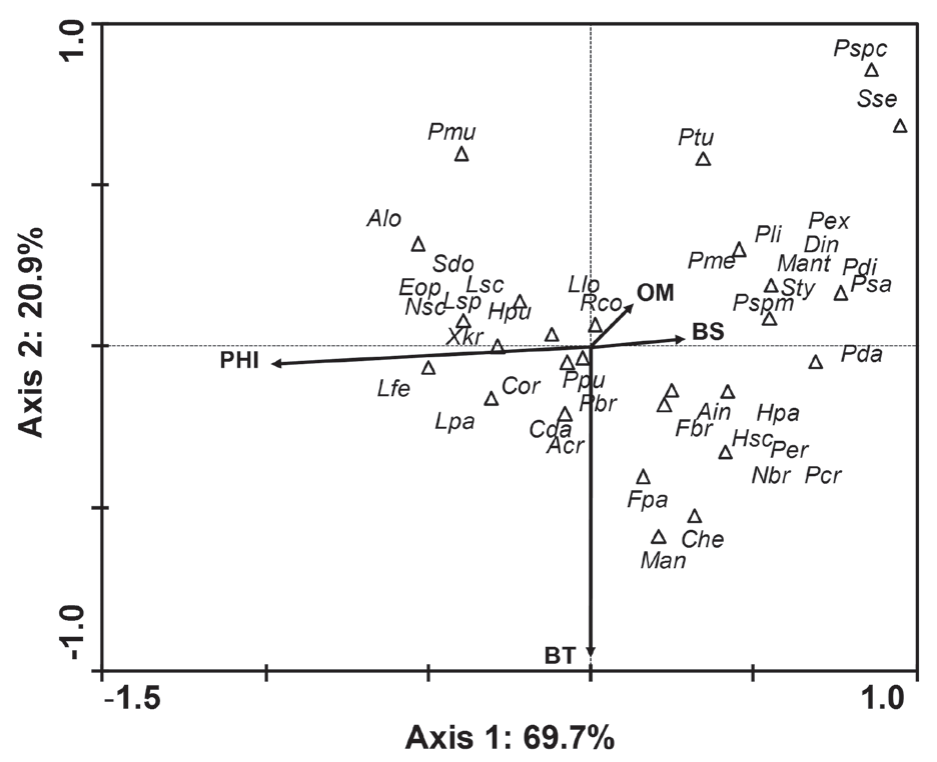

Fig. 2 - Results of canonical correspondence analysis, showing the correlation between abundance of decapod crustaceans and environmental factors sampled during the study period (January 1998 through December 1999) in the Ubatuba region. BT: bottom temperature, BS: bottom salinity, OM: organic matter, Acr: A. cribrarius, Ain: A. intrinsecus, Alo: A. longinaris, Cda: C. danae, Che: C. hellerii, Cor: C. ornatus, Din: D. insignis, Eop: E. oplophoroides, Fbr: F. brasiliensis, Fpa: F. paulensis, Hpa: H. paulensis, Hpu: H. pudibundus, Hsc: H. schmitti, Lfe: L. ferreirae, Llo: L. loxocheles, Lpa: L. paulensis, Lsc: L. schmitti, Lsp: L. spinosa, Man: M. angustus, Mant: M. antillensis, Nbr: N. brasiliensis, Nsc: N. schmitti, Pbr: P. brevidactylus, Pcr: P. criniticornis, Pda: P. dasypodus, Pdi: P. diogenes, Per: P. erythrops, Pex: P. exilis, Pli: P. lichtensteinii, Pme: P. mediterranea, Pmu: P. muelleri, Ppu: P. punctata, Psa: P. sayana, Pspc: P. spinicarpus, Pspm: P. spinimanus, Ptu: P. tuberculata, Rco: R. constrictus, Sdo: S. dorsalis, Sse: S. seticornis, Sty: S. typical, Xkr: X. kroyeri.

areas composed by fine sediments, which make burrowing easier (Dall et al. 1990, Pinheiro et al. 1996, 1997, Chacur et al. 2000, Chacur and Negreiros-Fransozo 2001, Bertini et al. 2001, Bertini and Fransozo 2004). On the other hand, the majority of brachyuran species, some hermit crabs and few penaeids were associated with coarser sediments. The finding of some burrowing species, such as the shrimps Farfantepenaeus spp., in locations with coarser sediments may be accounted for by the hypothesis proposed by Williams (1958). This author observed that in addition to a need for cover and the capacity to burrow, the respiratory requirements of shrimp may govern their burrowing habits. Substrates with a mixture of shell and sand (coarser substrate) would allow more rapid pumping during breathing than in pure beach sand or mud. This behavior indicates that shrimp adjust their burrowing not only to the ease with which they can enter the sediment but also to their respiratory requirements.

The association of hermit crabs with coarser sediment in this study is probably related to the greater availability of empty shells, because gastropods also tend to select sites with coarser sediment (Pires 1992). The availability of empty gastropod shells is a limiting resource for the survival of hermit crabs (Kellogg 1976, NegreirosFransozo et al. 1997), as molting hermits are exposed to predators and therefore urgently need a new and larger shell for protection. In addition, anomurans were positively related to the organicmatter content in the sediment. As mentioned by Fransozo et al. (1998), the organic content is very important in the distribution and maintenance of anomuran populations in Ubatuba Bay. Fransozo and colleagues noted that organic matter can be deposited among sediment particles or laid over 


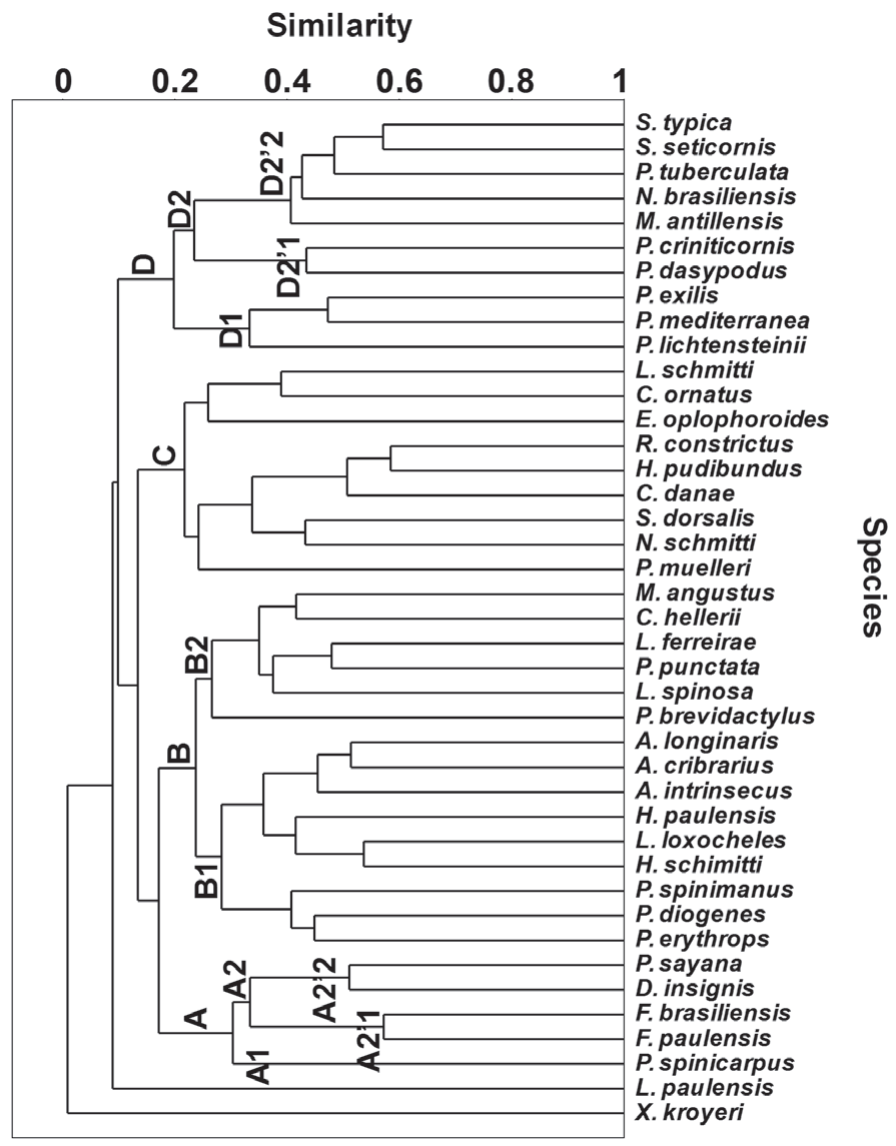

Fig. 3 - Grouping dendrogram (UPGMA) for the species captured during the study period (January 1998 through December 1999) in the Ubatuba region.

the substratum as a covering layer, and that both forms are food resources available for benthic organisms. These comprise the epifauna, infauna or meiofauna, including scavenger crustaceans, and may be consumed by other benthic animals.

The Ubatuba region is influenced by three water masses with different distributional patterns in summer and winter (Pires 1992): Coastal Water (CW, Temperature $>20^{\circ} \mathrm{C}$ and Salinity $<36$ ), Tropical Water (TW, $\mathrm{T}>20^{\circ} \mathrm{C}$ and $\left.\mathrm{S}>36\right)$ and South Atlantic Central Water (SACW, $\mathrm{T}<18^{\circ} \mathrm{C}$ and $\mathrm{S}<36$ ) (Castro Filho et al. 1987). According to Castilho et al. (2008), the intrusion of the SACW causes considerable changes to the resident communities, both positive and negative. Costa et al. $(2005,2007)$ observed a sharp decrease in bottom temperature at depths greater than $10 \mathrm{~m}$, during spring and summer 1998 and 1999, probably indicating the SAWC intrusion. This scenario may explain the occurrence of cold-water indicator species such as the shrimps $A$. longinaris and $P$. muelleri and the swimming crab P. spinicarpus, as mentioned by Boschi (1963, 1989), Pires-Vanin et al. (1993) and Dumont and D'Incao (2008). In this study, these species were associated with the lowest recorded temperatures and were concentrated at depths greater than $10 \mathrm{~m}$. On the other hand, species with a positive relationship with temperature tend to remain in shallower waters (less than $10 \mathrm{~m}$ deep) during the periods influenced by cold water masses, as observed by Costa and Fransozo (2004) and Fransozo et al. (2005) for the shrimp Rimapenaeus constrictus (Stimpson, 1874) and the caridean shrimp E. oplophoroides. 
As proposed by Mantelatto et al. (2004), the occurrence of the hermit crab L. loxocheles in lower temperatures is due to the optimum of geographical distribution of this species. It is mainly distributed along the southern Brazilian and Argentinean coasts (Melo 1999), where the water is cool year-round. The same hypothesis could be proposed for the hermit crab D. insignis, which occurs from the Brazilian coast (from Rio de Janeiro down to Rio Grande do Sul) to Uruguay and Argentina (Melo 1999).

In contrast, portunids are positively correlated with temperature. Pinheiro et al. (1996), Chacur and Negreiros-Fransozo (2001) and Bertini and Fransozo (2004) observed that A. cribrarius, $C$. danae and $C$. ornatus, respectively, were most abundant in higher temperatures, i.e., in areas uninfluenced by the SACW.

The abundance of the shrimp $X$. kroyeri showed only a slight positive correlation with temperature. Costa et al. (2007) suggested that during the period of SACW influx, this shrimp migrates to the northernmost part of the Brazilian southeast coast, because bottom temperatures lower than $21^{\circ} \mathrm{C}$ may be limiting. Xiphopenaeus kroyeri showed extremely high abundance during the study period, and thus can be considered a key species for trophic relationships of the local benthic fauna, and very important in the maintenance and equilibrium of the benthic community.

Salinity and the abundance of individuals were only weakly correlated in the present study. However, some investigators have suggested that salinity is important in the distribution mainly of certain brachyuran and penaeoid species. Of the species sampled here, the swimming crabs A. cribrarius and $C$. danae are euryhaline and tolerate wide salinity variations, which is necessary throughout their life cycles (Negreiros-Fransozo and Fransozo 1995, Pinheiro et al. 1996, Chacur and NegreirosFransozo 2001). The abundance of the shrimps $F$. paulensis and F. brasiliensis is also influenced by salinity variations. Costa et al. (2008), studying the distribution of juveniles of these species in an estuary in the Ubatuba region, observed that the spatial distribution of both species is influenced by salinity, but that $F$. paulensis is more tolerant for salinity variations than $F$. brasiliensis, since the juveniles of this latter species do not enter the estuary. D'Incao (1991), studying the biology of F. paulensis in the Lagoa dos Patos (Rio Grande do Sul, Brazil), one of the largest estuaries on the Brazilian coast, found only this species present in this lagoon.

Other environmental conditions besides those analyzed here, or intrinsic features of species may also modulate the distribution pattern and the abundance of benthic organisms. Fransozo et al. (2005, 2009), studying the distribution of the caridean shrimps E. oplophoroides and Nematopalaemon schmitti (Holthuis, 1950) in Ubatuba Bay, proposed that the presence of marine biogenic objects (shells, carapaces, etc.) and land-derived fragments (woods, sticks, leaves, etc.) are key factors determining the presence of these species in certain parts of the bay. The crab Hexapanopeus paulensis Rathbun, 1930 is mostly found associated with plant fragments and algae, and also attached to bryozoan colonies (Bertini et al. 2004). Probably, these factors also affected the abundance of individuals in this study.

Two of the species analyzed here have a symbiotic life style: . sayana, which is commonly found living with hermit crabs of the genera Dardanus, Petrochirus, Paguristes and Pagurus; and Minyocerus angustus (Dana, 1852), which lives in association with the sea star Luidia senegalensis (Lamarck, 1816) (Melo 1999). The abundance of these porcelain crabs is more closely related to the presence of their hosts than to the direct influence of environmental factors.

The species in the present study, some of tropical origin and others of temperate and subantarctic origin in the southwestern Atlantic Ocean, responded differently to environmental factors, according to their preferences and constraints. It is conceivable that decapod crustaceans adjust their 
distribution in space and time according to their intrinsic physiological limitations, possibly as a result of available resources in tropical regions. Although water temperature and sediment type offer a most convincing explanation for the abundance patterns of the decapod crustaceans observed in this study, it is important to realize that other factors such as competition and predation may also influence their abundance. The environmental and biotic factors jointly affect the occurrence of the species, influencing their biology. These factors, together with the adaptive processes acting on each species during evolution, may explain the species' capacity to tolerate environmental changes.

\section{ACKNOWLEDGMENTS}

We thank the NEBECC co-workers for their help during the fieldwork, Dr. Janet W. Reid for her great help with English language, and the anonymous reviewers for their valuable and helpful suggestions. The authors are grateful to the Fundação de Amparo à Pesquisa do Estado de São Paulo (FAPESP) for providing financial support (\#94/4878-8, \#97/12108-6, \#97/12106-3, \#97/12107-0,\#98/3134-6,\#10/50188-8), and to the Conselho Nacional de Desenvolvimento Científico e Tecnológico (CNPq). All sampling in this study has been conducted in compliance with current applicable state and federal laws.

\section{RESUMO}

Este estudo investigou a importância dos fatores ambientais sobre os padrões de abundância dos decápodos na costa sudeste brasileira. Amostragens foram feitas mensalmente de janeiro/1998 a dezembro/1999 em Ubatumirim e Mar Virado, região de Ubatuba, usando um barco de pesca camaroneiro equipado com redes doublerig. Foram selecionadas seis áreas adjacentes aos costões rochosos. Amostras de água de fundo foram coletadas usando garrafa de Nansen, para mensurar a temperatura e salinidade. Amostras de sedimento foram obtidas utilizando pegador de Van Veen, para determinação da textura e conteúdo de matéria orgânica. A associação dos fatores ambientais com a abundância das espécies foi verificada através da Análise de Correspondência Canônica $(\alpha=0,05)$. Quarenta e uma espécies de Decapoda foram utilizadas na análise multivariada. A análise indicou que a textura do sedimento (phi) e a temperatura foram os fatores mais fortemente correlacionados $(\mathrm{p}<0,05)$ com a abundância espacial e temporal das espécies. Considerando a região de estudo como zona de transição faunística, incluindo espécies de origem tropical e subantártica, as espécies responderam diferentemente aos fatores ambientais, principalmente à temperatura. Possivelmente os decápodos ajustem sua distribuição de acordo com suas limitações fisiológicas intrínsecas, como resultado dos recursos disponíveis.

Palavras-chave: espécies bentônicas, crustáceos decápodos, fatores ambientais, seleção de hábitat.

\section{REFERENCES}

ABELE LG. 1974. Species diversity of decapod crustaceans in marine habitats. Ecology 55: 156-161.

Alverson DL, Freeberg MH, Pope JG AND Murawski JA. 1994. A global assessment of fisheries bycatch and discards. FAO Fish Tech Pap 339: 1-233.

BERTINI G AND FRANSOZO A. 2004. Bathymetric distribution of brachyuran crab (Crustacea, Decapoda) communities on coastal soft bottoms off southeastern Brazil. Mar Ecol Prog Ser 279: 193-200.

Bertini G, Fransozo A AND CostA RC. 2001. Ecological distribution of three species of Persephona (Brachyura: Leucosiidae) in the Ubatuba region, São Paulo, Brazil. Nauplius 9(1): 31-42.

Bertini G, Fransozo A AND Melo GAS. 2004. Biodiversity of brachyuran crabs (Crustacea: Decapoda) from nonconsolidated sublittoral bottom on the northern coast of São Paulo State, Brazil. Biodivers Conserv 13: 2185-2207.

Bertini G, Fransozo A AND Negreiros-Fransozo ML. 2010. Brachyuran soft-bottom assemblage from marine shallow waters in the southeastern Brazilian littoral. Mar Biodiv 40: 277-291.

Boschi EE. 1963. Los camarones comerciales de la família Penaeidae de la costa Atlántica de America del Sur. Bol Inst Biol Mar 3: 1-39.

BosCHI EE. 1989. Biología pesquera del langostino del litoral Patagónico de Argentina (Pleoticus muelleri). Contrib INIDEP 646: 1-71.

BosCHI EE. 2000. Species of decapod crustaceans and their distribution in the American marine zoogeographic provinces. Rev Invest Desarr Pesq 13: 7-136. 
Castilho AL, Costa RC, Fransozo A And Boschi EE. 2007. Reproductive pattern of the South American endemic shrimp Artemesia longinaris (Decapoda, Penaeidae), off the coast of São Paulo state, Brazil. Rev Biol Trop 55(1): $39-48$.

Castilho AL, Pie Mr, Fransozo A, Pinheiro AP AND CosTA RC. 2008. The relationship between environmental variation and species abundance in shrimp community (Crustacea: Decapoda: Penaeoidea) in south-eastern Brazil. J Mar Biol Assoc UK 88(1): 119-123.

CAstro RH, Costa RC, Fransozo A And Mantelatto FLM. 2005. Population structure of seabob shrimp Xiphopenaeus kroyeri (Heller, 1862) (Crustacea: Penaeoidea) in the littoral of São Paulo, Brazil. Sci Mar 69: 105-112.

Castro-Filho BM, Miranda LB and MyaO SY. 1987. Condições hidrográficas na plataforma continental ao largo de Ubatuba: variações sazonais e em média escala. Bol Inst Oceanogr 35(2): 135-151.

Chacur MM, Mansur CB AND Negreiros-Fransozo ML. 2000. Distributional patterns, seasonal abundance and moult cycle of Callinectes danae Smith, 1869 in the Ubatuba region, Brazil. Nauplius 8(2): 215-226.

Chacur MM AND NegreIROS-Fransozo ML. 2001. Spatial and seasonal distributions of Callinectes danae (Decapoda, Portunidae) in Ubatuba Bay, São Paulo, Brazil. J Crustacean Biol 21(2): 414-425.

Colloca F, Cardinale M and Bellucio A. 2003. Pattern of distribution and diversity of demersal assemblages in the central Mediterranean Sea. Estuar Coast Shelf Sci 56: 469-480.

Costa RC And Fransozo A. 2004. Abundance and ecologic distribution of the shrimp Rimapenaeus constrictus (Crustacea: Penaeidae) on the northern coast of São Paulo State, Brazil. J Nat Hist 38: 901-912.

Costa RC, Fransozo A, Freire FAM and Castilho AL. 2007. Abundance and ecological distribution of the "setebarbas" shrimp Xiphopenaeus kroyeri (Heller, 1862) (Decapoda: Penaeoidea) in three bays of the Ubatuba region, South-eastern Brazil. Gulf Caribb Res 19: 33-41.

Costa RC, Fransozo A, Melo Gas and Freire FAM. 2003. An illustrated key for Dendrobranchiata shrimps from the northern coast of São Paulo State, Brazil. Biota Neotropica 3(1): http://www.biotaneotropica.org.br/v3n1/ pt/abstract?identification-key+BN01503012003.

Costa RC, Fransozo A and Negreiros-Fransozo ML. 2005. Ecology of the rock shrimp Sicyonia dorsalis Kingsley, 1878 (Crustacea: Sicyoniidae) in a subtropical region of Brazil. Gulf Caribb Res 17: 49-56.

Costa RC, Fransozo A And Pinheiro AP. 2004. Ecological distribution of the shrimp Pleoticus muelleri (Bate, 1888) (Decapoda: Penaeoidea) in southeastern Brazil. Hydrobiologia 529: 195-203.

Costa RC, Lopes M, CASTILHO AL, Fransozo A AND SimÕes SM. 2008. Abundance and distribution of juvenile pink shrimps Farfantepenaeus spp. in a mangrove estuary and adjacent bay on the northern shore of São Paulo State, southeastern Brazil. Invertebr Reprod Dev 52(1-2): 51-58.
D’InCAO F. 1991. Pesca e biologia de Penaeus paulensis na Lagoa dos Patos, RS. Atlântica 13: 159-169.

Dall W, Hill BJ, Rothlisberg PC AND Sharples DJ. 1990. The biology of the Penaeidae. In: Blaxter JHS and Southward AJ (Eds), Advances in Marine Biology, San Diego: Academic Press, USA, 489 p.

DE GRAVE S ET AL. 2009. A classification of living and fossil genera of decapod crustaceans. Raffles B Zool 21: 1-109.

DE LÉO FC AND PIRES-VANIN AMS. 2006. Benthic megafauna communities under the influence of the South Atlantic Central Water intrusion onto the Brazilian SE shelf: a comparison between an upwelling and a non-upwelling ecosystem. J Marine Syst 60: 268-284.

DUMONT LFC AND D'InCAO F. 2008. Distribution and abundance of the Argentinean (Artemesia longinaris) and red (Pleoticus muelleri) prawns (Decapoda-Penaeoidea) in Southern Brazil during the commercial double rig trawl fishery season. Nauplius 16(2): 83-94.

ESCOBAR-BRIONES EG, GAYTÁN-CABALLERO A AND LEGENDRE P. 2008. Epibenthic megacrustaceans from the continental margin, slope and abyssal plain of the Southeastern Gulf of Mexico: factors responsible for variability in species composition and diversity. Deep-Sea Res Pt II 55: 2667-2678.

FERREIRA RS, VIEIRA RRR AND D'INCAO F. 2010. The marine and estuarine shrimps of the Palaemoninae (Crustacea: Decapoda: Caridea) from Brazil. Zootaxa 2606: 1-24.

Fransozo A, Bertini G, Braga AA AND NegreirosFRANSOZO ML. 2008. Ecological aspects of hermit crabs (Crustacea, Anomura, Paguroidea) off the northern coast of São Paulo State, Brazil. Aquat Ecol 42: 437-448.

Fransozo A, Costa RC, Mantelatto FLM, Pinheiro MAA AND SANTOS S. 2002. Composition and abundance of shrimp species (Penaeidea and Caridea) in Fortaleza Bay, Ubatuba, São Paulo, Brazil. In: Escobar-Briones E and Alvarez F (Eds), Modern Approaches to the Study of Crustacea, New York: Kluwer Academic/Plenum Publishers, USA, p. 117-123.

Fransozo A, Fernandes-Góes LC, Fransozo V, Góes JM, Cobo VJ, TeIXEIRA GM AND GREgATI RA. 2011. Marine anomurans (Decapoda) from the non-consolidated sublittoral bottom at the southeastern coast of Brazil. Crustaceana 84: 435-450.

Fransozo A, MANTELATTO FLM, Bertini G, FernANDES-GÓES LC AND MARTINELLI JM. 1998. Distribution and assemblages of anomuran crustaceans in Ubatuba Bay, North coast of São Paulo State, Brazil. Acta Biol Venez 18(4): 17-25.

Fransozo A, Negreiros-Fransozo ML, Mantelatto FLM, PINHEIRO MAA AND SANTOS S. 1992. Composição e distribuição dos Brachyura (Crustacea, Decapoda) do sublitoral não consolidado na Enseada da Fortaleza, Ubatuba (SP). Rev Bras Biol 52: 667-675.

Fransozo V, Castilho AL, Freire FAM, Furlan M, Almeida AC, TEIXEIRA GM AND BAEZA JA. 2009. Spatial and temporal distribution of the shrimp Nematopalaemon schmitti (Decapoda: Caridea: Palaemonidae) at a subtropical enclosed bay in South America. J Mar Biol Assoc UK 89 (8): 1581-1587. 
Fransozo V, Costa RC, Bertini G AND CoBo VJ. 2005. Population biology of spine shrimp Exhippolysmata oplophoroides (Holthuis) (Caridea, Hippolytidae) in a subtropical region, São Paulo, Brazil. Rev Bras Zool 22 (4): 1078-1084

GARCIA S AND LE Reste L. 1981. Life cycles, dynamics, exploitation, and management of coastal penaeid shrimp stocks. FAO Fish Tech Pap 203: 1-215.

HolThuis LB. 1993. The recent genera of the caridean and stenopodidean shrimps (Crustacea, Decapoda), with an appendix on the Order Amphionidacea. In: Fransen CHJM and Van Achterberg C (Eds), Leiden: Nationaal Natuurhistorisch Museum, Netherlands, 328 p.

KELLOGG CW. 1976. Gastropod shells: a potentially limiting resource for hermit crabs. J Exp Mar Biol Ecol 22: 101-111.

LUI KKY, NG JSS AND LEUNG KMY. 2007. Spatio-temporal variations in the diversity and abundance of commercially important Decapoda and Stomatopoda in subtropical Hong Kong Waters. Estuar Coast Shelf Sci 72: 635-647.

Mantelatto FLM AND Fransozo A. 2000. Brachyuran community in Ubatuba Bay, Northern Coast of São Paulo State, Brazil. J Shellfish Res 19: 701-709.

Mantelatto FLM, Martinelli JM AND Fransozo A. 2004. Temporal-spatial distribution of the hermit crab Loxopagurus loxochelis (Decapoda: Diogenidae) from Ubatuba Bay, São Paulo State, Brazil. Rev Biol Trop 52(1): 47-55.

Meireles AL, Terossi M, Biagi R And Mantelatto FL. 2006. Spatial and seasonal distribution of the hermit crab Pagurus exilis (Benedict, 1892) (Decapoda: Paguridae) in the southwestern coast of Brazil. Rev Biol Mar Oceanogr 41(1): 87-95.

Melo GAS. 1996. Manual de identificação dos Brachyura (caranguejos e siris) do litoral brasileiro. São Paulo: Plêiade/FAPESP, Brasil, 604 p.

MELo GAS. 1999. Manual de identificação dos Crustacea Decapoda do litoral brasileiro: Anomura, Thalassinidea e Astacidea. São Paulo: Plêiade/FAPESP, Brasil, 551 p.

NegreIros-Fransozo ML AND Fransozo A. 1995. On the distribution of Callinectes ornatus Ordway, 1863 and Callinectes danae Smith, 1869 (Brachyura, Portunidae) in the Fortaleza Bay, Ubatuba, Brazil. Iheringia Ser Zool 79: 13-25.

Negreiros-Fransozo ML, Fransozo A, MANTELATto FLM, PINHEIRO MAA AND SANTOS S. 1997. Anomuran species (Crustacea, Decapoda) and their ecological distribution at Fortaleza Bay sublittoral, Ubatuba, São Paulo, Brazil. Iheringia, Ser Zool 83: 187-194.

Negreiros-Fransozo ML, MANTELATto FLM AND Fransozo A. 1999. Population biology of Callinectes ornatus Ordway, 1863 (Decapoda, Portunidae) from Ubatuba (SP), Brazil. Sci Mar 63(2): 157-163.
Pauly D, Christensen V, Guénette S, Pitcher TJ, Sumaila UR, WALTERS CJ, WATSON R AND ZELleR D. 2002. Towards sustainability in world fisheries. Nature 418: 689-695.

Pérez Farfante I AND Kensley B. 1997. Penaeoid and Sergestoid shrimps and prawns of the world. Keys and diagnoses for the families and genera. Paris: Éditions du Muséum National d'Histoire Naturelle, France, 233 p.

Pinheiro MAA, Fransozo A and Negreiros-Fransozo ML. 1996. Distribution patterns of Arenaeus cribrarius (Lamarck, 1818) (Crustacea, Portunidae) in Fortaleza Bay, Ubatuba (SP), Brazil. Rev Bras Biol 56(4): 705-716.

Pinheiro MAA, Fransozo A AND Negreiros-Fransozo ML. 1997. Dimensionamento e sobreposição de nichos dos portunídeos (Decapoda, Brachyura), na Enseada da Fortaleza, Ubatuba, São Paulo, Brasil. Rev Bras Zool 14(2): 371-378.

PIRES AMS. 1992. Structure and dynamics of benthic megafauna on the continental shelf offshore of Ubatuba, southeastern Brazil. Mar Ecol Prog Ser 86: 63-76.

PIREs-VANIN AMS, ROSSI-WONGTSCHOWSKI CLB, AIDAR E, Mesquita SL, SoAres LSH, KatsuragaWA M AND MATSUURA Y. 1993. Estrutura e função do ecossistema de plataforma continental do Atlântico Sul brasileiro: síntese e dos resultados. Publ Esp Inst Oceanogr 10: 217-231.

RHYNE AL AND LIN J. 2006. A western Atlantic peppermint shrimp complex: redescription of Lysmata wurdemanni, description of four new species, and remarks on Lysmata rathbunae (Crustacea: Decapoda: Hippolytidae). B Mar Sci 70(1): 165-204.

SCElzo MA, MARTÍNEZ ARCA J AND LUCERO NM. 2002. Diversidad, densidad y biomasa de la macrofauna componente de los fondos de pesca 'camarón-langostino', frente a Mar del Plata, Argentina (1998-1999). Rev Invest Desarr Pesq 15: 43-65.

SuGUIO K. 1973. Introdução à Sedimentologia. São Paulo: Edgard Blucher/EDUSP, Brasil, 317 p.

SUMIDA PYG AND PIRES-VANIN AMS. 1997. Benthic associations of the shelf break and upper slope off Ubatuba-SP, South-eastern Brazil. Estuar Coast Shelf Sci 44: 779-784.

TUCKER M. 1988. Techniques in Sedimentology. Boston: Blackwell Scientific Publications, USA, 394 p.

WENTWORTH CK. 1922. A scale of grade and terms for clastic sediments. J Geol 30: 377-392.

WiLliams AB. 1958. Substrates as a factor in shrimp distributions. Limnol Oceanogr 3(3): 283-290.

ZAR JH. 1999. Biostatistical Analysis. New Jersey: PrenticeHall, Englewood Cliffs, USA, 663 p. 